\title{
Geocryological conditions triggering thermokarst processes in Central Yakutia
}

\author{
Nataliia Nesterova ${ }^{1,2, *}$ Olga Makarieva ${ }^{1,3}$, Alexander Fedorov ${ }^{3}$, and Andrey Shikhov ${ }^{4}$ \\ ${ }^{1}$ Saint-Petersburg State University, 199034 Saint-Petersburg, Russia \\ ${ }^{2}$ State Hydrological Institute, 199053 Saint-Petersburg, Russia \\ ${ }^{3}$ Melnikov Permafrost Institute, 677010 Yakutsk, Russia \\ ${ }^{4}$ Perm State University, 614990 Perm, Russia
}

\begin{abstract}
The use of the Central Yakutia Landsat images revealed an increase in the area of thermokarst lakes by two times for the Suola and Taatta River basins and a quarter times in the Tanda River basin during the period 2000-2019. The abrupt increase in the lakes area is due to shortterm periods of abnormal rising in the active layer temperature, which are caused by high values of snow water equivalent and total annual precipitation. Increased soil moisture and the warming effect of snow cover led to the decrease of the intensity of soil freezing and increase of the temperature of the ground top layer. The combination of these factors triggered the activation of thermokarst processes, which led to a sharp, more than 1.5 times, increase of the thermokarst lakes area in 2007-2008.
\end{abstract}

\section{Introduction}

The most common lakes in Central Yakutia are thermokarst lakes, which present $80 \%$ of the total number of lakes in Yakutia [1].

There is a multidirectional dynamic of the number and area of thermokarst lakes in different regions of Russia and the world under climate change conditions [2, 3]. For the territory of Central Yakutia, an increase in the total area and number of thermokarst lakes was detected, ranging from two to three times for different regions in the period 1980-2009 $[4,5]$. However, the authors emphasize that the changes are cyclical, following the alternation of high-water and low-water years.

The aim of this study is to investigate the conditions that lead to the nonlinear dynamics thermokarst lakes development in Central Yakutia, based on the analysis of remote sensing data and detailed observations of the state of active layer of soil. The task of understanding the conditions that contribute to the activation of thermokarst processes is extremely relevant, when significant climate changes are predicted in the territory of Central Yakutia [6].

\footnotetext{
* Corresponding author: nnesterova1994@gmail.com
} 


\section{Study area, data and methods}

\subsection{Study areas}

The study area belongs to the South-Eastern part of the Central Yakutia lowland with an average absolute height of $250 \mathrm{~m}$. The climate of the region is sharply continental. The average annual air temperature at Yakutsk weather station was $-8.8^{\circ} \mathrm{C}$ for the period 19662018. The average annual precipitation is about $240 \mathrm{~mm}$, and the main amount $(75-85 \%)$ falls in the summer [7].

Central Yakutia is located at the area of continuous permafrost zone. The landscape of the territory is grassy-lingonberry larch on permafrost-taiga field and podzol soils [8]. One of the main features of the region is weak development of the river network and wide spread of erosion-thermokarst basins [7]. The most mature thermokarst forms, the alases, are covered with meadow-steppe vegetation with saline soils.

\subsection{Remote sensing data}

In this study, 54 images from Landsat satellites (TM, ETM+, OLI sensors) were obtained to determine the changes of thermokarst lakes area for the period from 2000 to 2019. The images of summer season (from June to September) and relatively large lakes with an area of more than 1 ha were considered. The method of lake allocation included the following steps: 1) conversion of brightness values in spectral channels from the initial values to reflectivity and atmospheric correction using the DOS method, using the Qgis semiautomated image classifier (SCP) module; 2) selection of water surface by the threshold value of the normalized difference water index NDWI (the threshold is set to 0.3 ); 3) conversion to a vector data format, calculation of areas, removal of objects with an area of less than 1 ha.

Four river basins with areas ranging from 1270 to $8290 \mathrm{~km}^{2}$ were investigated, characterized by a significant distribution of alas (Fig. 1, Table 1). The share of the alas area estimated on the basis of the results by [9] varies from $4.9 \%$ within the Tanda River basin to $9.7 \%$ in the Suola River basin - Bedeme.

Table 1. Distribution of alas and thermokarst lakes in river basins.

\begin{tabular}{|c|c|c|c|c|c|c|c|}
\hline Index & $\begin{array}{c}\text { River } \\
\text { basin }\end{array}$ & $\begin{array}{c}\text { Basin } \\
\text { area, } \\
\mathrm{km}^{2}\end{array}$ & $\begin{array}{c}\text { Alas } \\
\text { area, } \\
\mathrm{km}^{2} / \%\end{array}$ & $\begin{array}{c}\text { Lake area, } \\
09.06 .2019, \\
\mathrm{~km}^{2} / \%\end{array}$ & $\begin{array}{c}\text { Number } \\
\text { of } \\
\text { images }\end{array}$ & $\begin{array}{c}\text { Min lake } \\
\text { area, } \mathrm{km}^{2} \\
\text { /year }\end{array}$ & $\begin{array}{c}\text { Max lake } \\
\text { area, } \mathrm{km}^{2} \\
\text { /year }\end{array}$ \\
\hline $\begin{array}{c}\text { Suola } \\
\text { River- } \\
\text { Buteidah }\end{array}$ & 1270 & $81.7 / 6.4$ & $17.85 / 1.41$ & 58 & $8.89 / 2003$ & $\begin{array}{c}19.4 / \\
2018\end{array}$ \\
\hline 3306 & $\begin{array}{c}\text { Tanda } \\
\text { River - } \\
\text { Baria }\end{array}$ & 2000 & $97.9 / 4.9$ & $27.67 / 1.38$ & 11 & $\begin{array}{l}23.4, \\
2001\end{array}$ & $\begin{array}{c}29.4 / \\
2018\end{array}$ \\
\hline \multirow{2}{*}{3628} & $\begin{array}{c}\text { Taatta } \\
\text { River- } \\
\text { Uolba }\end{array}$ & 8290 & $776 / 9.4$ & $213.28 / 2.57$ & 7 & 118,2001 & $225 / 2018$ \\
\hline $\begin{array}{c}\text { Suola } \\
\text { River- } \\
\text { Bedeme }\end{array}$ & 3380 & $326 / 9.7$ & $66.05 / 1.95$ & 27 & $\begin{array}{l}34.0, \\
2004\end{array}$ & $\begin{array}{c}70.8 / \\
2008\end{array}$ \\
\hline
\end{tabular}




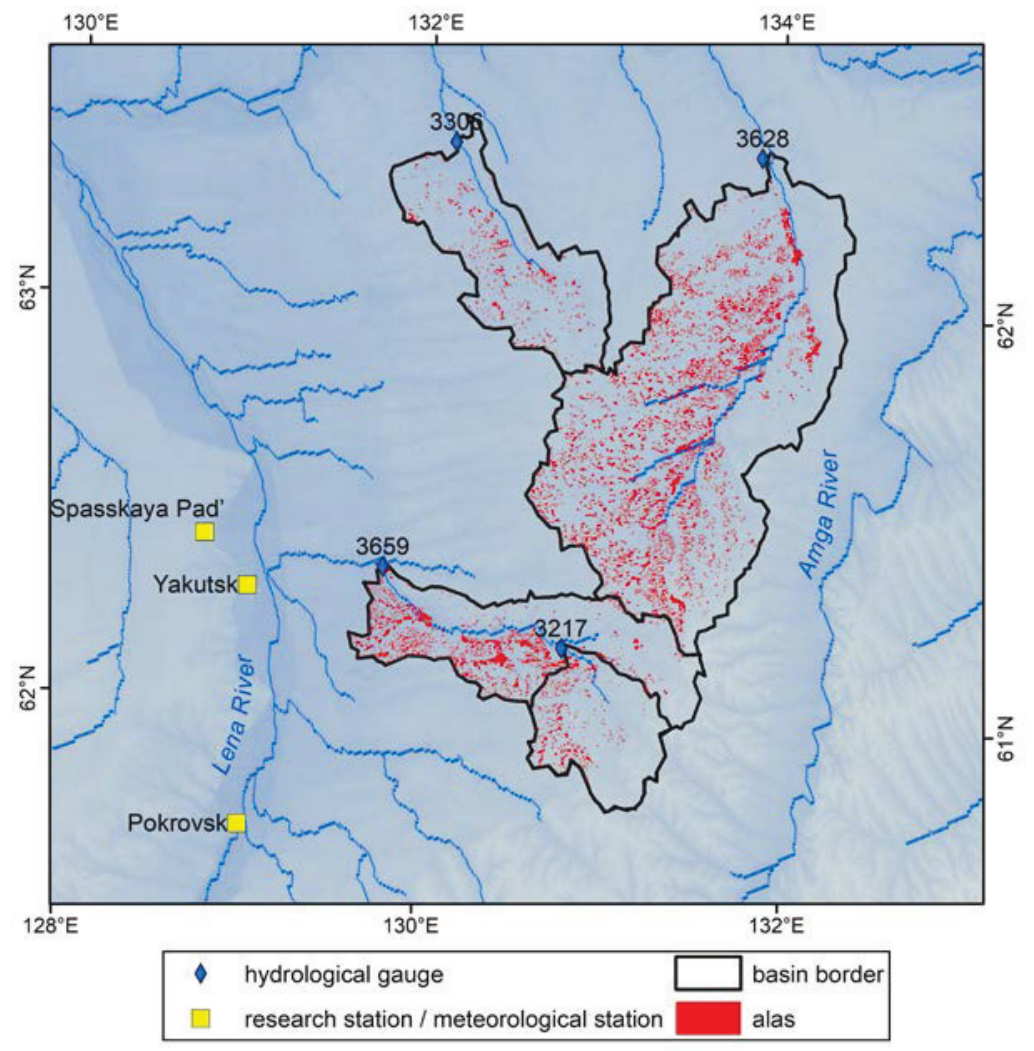

Fig. 1. The study area.

\subsection{The data of land-based observations}

The data of observations at the Spasskaya Pad' research station were used to assess the relationship between the characteristics of active layer and snow cover with the dynamics of the thermokarst lakes area. They included daily observations of soil moisture at depths of $0.1,0.2,0.4,0.6,0.8 \mathrm{~m}$ and temperature to a depth of $1.2 \mathrm{~m}$ for the period 1998-2010 [10, 11 ], as well as the on soil moisture (up to $1.5 \mathrm{~m}$ ) and soil temperature (up to $3.2 \mathrm{~m}$ ), which were collected 1-2 times a month for the period 1998-2018 (data provided by A. N. Fedorov, Melnikov Permafrost Institute). In this study, we used the data from the sites located in larch forest landscape. In [10] it is shown that the data of the Spasskaya Pad' station are representative for typical landscape conditions of the Central Yakutia. In the analysis we also used the data on snow cover and soil temperature at a depth of $1.6 \mathrm{~m}$ at Yakutsk weather station.

\section{Results}

The area of thermokarst lakes increased twice within three of the four study basins in 20002019. Fig. 2 shows the dynamic of changes of the lake area in the Suola River basin Buteidah in the period 2000-2019. This basin is characterised by the largest number of available satellite images without clouds (without 2007 and 2012). Maximum development of lake is found in 2007 [5; 10], 2008 and 2018, minimum - for the period 2001-2004. 


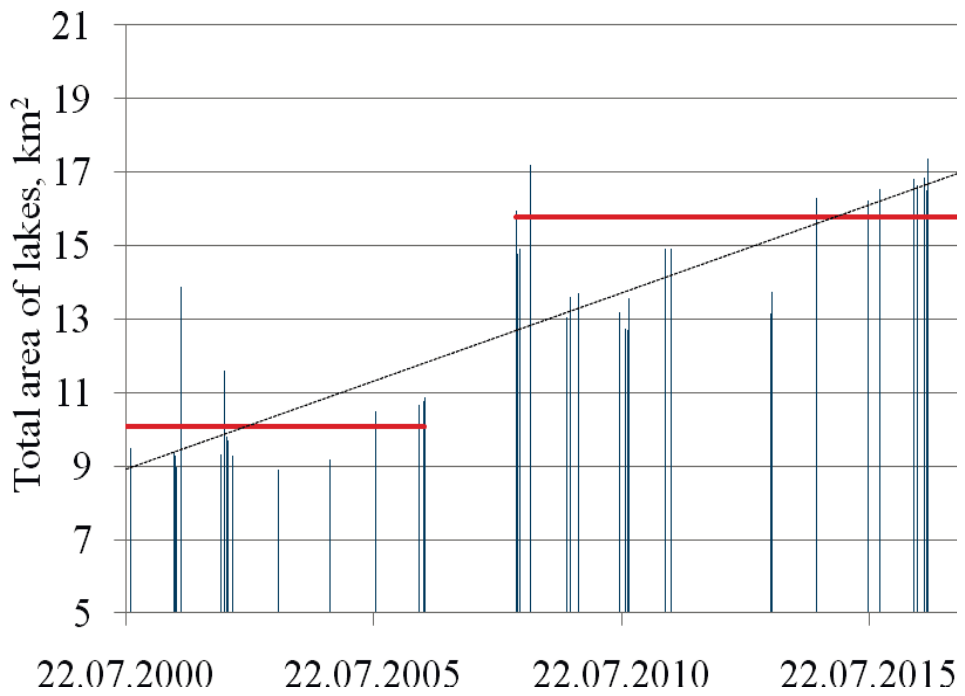

Fig. 2. Dynamic of thermokarst lakes area in the Suola River basin - Buteidah for the period 2000 2019 ; the red line corresponds to the average area of the lakes for two periods 2000-2006 and 20082019 years.

It is important to note that the changes of area occur abruptly despite the presence of a general increasing linear trend. Thus, in 2007-2008, there was a sharp increase of the lakes area, which has determined its dynamics in subsequent years (Fig. 2). During 2000-2006, the average area of lakes in the Suola River basin - Buteidah was $10.0 \mathrm{~km}^{2}$, and in 2008$2019-15.8 \mathrm{~km}^{2}$.

A sharp increase in the area of lakes in 2007-2008 was preceded by a period (20052008) with abnormally snowy winters. During this period total annual precipitation was above normal by $20-43 \%$. The average value of maximum snow water equivalent at the beginning of snowmelt at Yakutsk station for the 1966-2018 was $59 \mathrm{~mm}$. In 2005-2007 it amounted to 88,86 and $78 \mathrm{~mm}$ exceeding the norm by 50, 46 and $32 \%$. Mean annual precipitation was $303 \mathrm{~mm}$ for the period 2005-2008 (with a norm of $237 \mathrm{~mm}$ ). However, there is no direct functional relationship between the area of thermokarst lakes and the amount of solid, liquid or total sums of precipitation.

In [10] the geocryological consequences of significant amounts of precipitation are in 2005-2008 are discussed. Abnormally high snow water equivalent and significant rains in previous autumn have led to continuous period of high soil moisture content in the Central Yakutia. For example, the average moisture content of the upper 80-centimeter layer of soil during the warm period (May - September) was $24 \%$ of the dry weight in 2006 , compared to $11 \%$ in 2003 . The humidity of the upper $10-\mathrm{cm}$ layer amounted to $50 \%$ and $80-\mathrm{cm}$ layer to $46 \%$ on the $1^{\text {st }}$ of October 2006 (before soil freezing), so the soil was in a state of complete saturation at the beginning of snowmelt in 2007.

We have studied the relationship between 1) maximum area of thermokarst lakes and 2) the values of soil moisture (average during warm period and maximum daily) of the upper 1-meter soil layer in antecedent year for the period 2000-2019 in the Suola River basin Buteidah. The correlation coefficient is 0.63 for warm period average soil moisture and 0.80 for maximum daily soil moisture, respectively. It is obvious that the dependences are of a qualitative nature since they can be constructed only for a short period, characterized by a sharp change in the values under consideration. In the future, the area of the lakes will 
most likely not decrease to the level of the 2000s in dry years, when soil moisture was minimal.

The thermal regime of soils changed as a result of the combined action of two interrelated factors - significant soil moisture and abnormally high snow equivalent. The increase of soil moisture, due to high snow water equivalent in winter and significant precipitation in summer in consequent years prevented soil freezing and resulted in sharp increase of soil temperature. Minimum and maximum temperature at $1.2 \mathrm{~m}$ depth was $-10.4{ }^{\circ} \mathrm{C}$ and $0.0{ }^{\circ} \mathrm{C}$ in 2004 , and $3.1{ }^{\circ} \mathrm{C}$ and $+2.2{ }^{\circ} \mathrm{C}$ in 2007 at Spasskaya Pad' station. The maximum thaw depth varied from 1.37 to $1.57 \mathrm{~cm}$ before 2004, and it was $1.67 \mathrm{~cm}$ in 2007 [10].

The graph of maximum area of thermokarst lakes and maximum soil temperature at a depth of $1.6 \mathrm{~m}$ at Yakutsk station is plotted on Fig. 3. The linear correlation coefficient between values with a 1 -year shift is 0.39 , but it is clearly seen that the direction of changes in the lakes area repeats the trends of soil temperature with a delay of 1 year. The increase in soil temperature from 1.9 to $7.5^{\circ} \mathrm{C}$ in $2004-2006$ is followed by a sharp increase of lakes area from 8.9 to $17.2 \mathrm{~km}^{2}$ in 2007-2008. Similar situation is observed in 2000-2001: a sharp increase of maximum soil temperature from 4.3 to $6.9^{\circ} \mathrm{C}$ in 2000 is accompanied by increase of the lakes area from 9.5 to $13.9 \mathrm{~km}^{2}$.

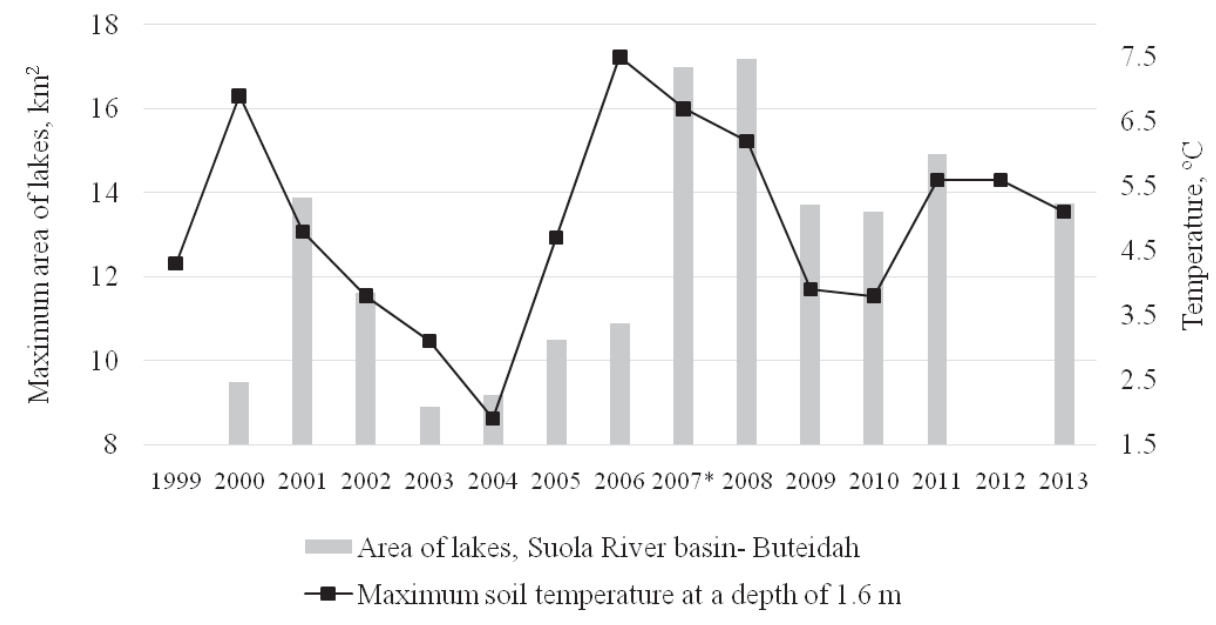

Fig. 3. The maximum area of thermokarst lakes and the maximum soil temperature at a depth of 1.6 $\mathrm{m}$ at the Yakutsk station; * provided that the area of lakes in 2007 is not lower than the value of 2008.

\section{Conclusions}

On the basis of Landsat satellite images, a tendency to increase the thermokarst lakes area at Suola, Tanda and Taatta River basins of the Central Yakutia for the period 2000-2019 has been shown. The lakes area has doubled over a period of 20 years in the Suola and Taatta basins and increased by $25 \%$ in the Tanda River basin. It was found that the increase of lakes area occurs abruptly despite the presence of a general linear trend.

The dependence between the state of active layer of permafrost, the underlying surface and a sharp increase in the area of thermokarst lakes in the Central Yakutia was revealed. The period 2005-2008 is characterized by abnormally high values of snow water equivalent and annual precipitation, exceeding the norm by $20-43 \%$, which led to an increase in soil moisture over a long period. In 2006, the average humidity of the upper 80-centimetre soil layer during the warm period was more than 2 times higher than in the dry year 2003. Increased soil moisture and high snow water equivalent led to the decrease of soil freezing 
intensity, temporary increase of soil temperature and the depth of active layer. The combination of these factors triggered the activation of thermokarst processes that led to a sharp increase in the lakes area in 2007-2008.

Thus, the main factor that leads to a violation of stable state of thermokarst forms is short-term (1-3 years) periods of abnormal increase in the active layer temperature. Such periods may be caused by a rare combination of hydrometeorological conditions. The established dependencies can be used to predict the development of thermokarst lakes in future, both on the basis of observations of the state of permafrost and model calculations.

The study was carried within the research project №19-35-50030 of Russian Foundation of Basic Research and also supported by research grant of St. Petersburg State University (Event 6, TRAIN2019_1, ID: 38360672).

\section{References}

1. M. I. Nestereva, Young scientist, 9, 79-82 (2012)

2. D.K. Swanson, Arctic, Antarctic, and Alpine Research, 51(1), 265-279 (2019)

3. V. I. Kravtsova, A. G. Bystrova, Earth's Cryosphere, XIII (2), 16-26 (2009)

4. T. V. Rodionova, Studies of the thermokarst lakes dynamics in various areas of the permafrost zone of Russia from space images. PhD Thesis (Moscow State University, Moscow, 2013)

5. V. I. Kravtsova, T. V. Tarasenko, Earth's Cryosphere, XV (3), 31-42 (2011)

6. D. A. Streletskiy, L. J. Suter, N. I. Shiklomanov, B. N. Porfiriev, D. O. Eliseev, Environmental Research Letters, 14(2), 025003 (2019)

7. N. P. Bosikov, Evolution of the alas of Central Yakutia (IMZ SB RAS, Yakutsk, 1991)

8. M.S. Ivanov, Cryogenic structure of Quaternary deposits of the Leno-Aldan depression Nauka, (Novosibirsk, 1984)

9. Ya. I. Torgovkin, A. A. Shestakova, A. I. Vasiliev, Problems of regional ecology, 6, 138-140 (2018)

10. Y. Iijima, A.N. Fedorov, H. Park, K. Suzuki, H. Yabuki, T.C. Maximov, T. Ohata, Permafrost and Periglacial Processes, 21, 30-41 (2010)

11. GAME-Siberia and Frontier Observational Research System for Global Change. Dataset for Water and Energy Cycle in Siberia (Version 1), (edited by Rikie Suzuki and Tetsuo Ohata, GAME-Siberia and FORSGC, 2003) 